\section{AMERICAN-EURASIAN JOURNAL OF SUSTAINABLE AGRICULTURE}

ISSN: 1995-0748, EISSN: 1998-1074

2019, Volume (13), Issue(4):pages(18-26)

DOI: 10.22587/aejsa.2019.13.4.2

Published Online in Septemberhttp://www.aensiweb.com/AEJSA/

\title{
Effect of Nitrogen Addition to Organic + Inorganic Liquid Fertilizers and Seasons on Productivity of Tea Shoots
}

\author{
Zakarias F.M. Hukom $^{1,2 *}$, Didik Indradewa ${ }^{3}$, Benito H. Purwanto ${ }^{4}$, \& Eka T.S. Putra ${ }^{3}$ \\ ${ }^{1}$ Doctoral Program, Department of Agronomy, Faculty of Agriculture, Universitas Gadjah Mada. Jln. Flora, Bulaksumur, Yogyakarta 55281, \\ Indonesia \\ ${ }^{2}$ Department of Agroecotechnology, Faculty of Agriculture, Universitas Pattimura, Jln. Ir. M. Putuhena, Poka, Ambon, Maluku, Indonesia \\ ${ }^{3}$ Department of Agronomy, Faculty of Agriculture, Universitas Gadjah Mada. Jln. Flora, Bulaksumur, Yogykarta 55281, Indonesia \\ ${ }^{4}$ Department of Soil Science, Faculty of Agriculture, Universitas Gadjah Mada. Jln. Flora, Bulaksumur, Yogykarta 55281, Indonesia
}

Received date: 12 July 2019, Accepted date: 28 November 2019, Online date: 2 December 2019

Address for Correspondence:

Zakarias F.M. Hukom, 1Doctoral Program, Department of Agronomy, Faculty of Agriculture, Universitas Gadjah Mada. Jln. Flora, Bulaksumur, Yogyakarta 55281, Indonesia

E-mail: zakaria.hukom19@gmail.com Tele.+6281227980289

Copyright $@ 2019$ by authors and American-Eurasian Network for Scientific Information.

This work is licensed under the Creative Commons Attribution International License (CC BY).

http://creativecommons.org/licenses/by/4.0/

\section{(i) Open Access}

\begin{abstract}
The tea plant (Camellia sinensis (L.) O. Kuntze) is the most popular beverage plant in the world because of its high bioactive compounds and antioxidant properties contained in its shoots. The productivity of tea shoots highly depends certain factors, including fertilization. In a commercial tea plantation, the application of $\mathbf{N}$ fertilizer plays essential roles in determining the productivity of tea shoots. It is commonly implemented by mixing $\mathbf{N}$ with organic + inorganic liquid fertilizer. However, the response of tea plant to $\mathbf{N}$ fertilizer varies depending on its requirement and climate condition. This study investigated the effect of Nitrogen addition in organic + inorganic liquid fertilizer on the productivity of tea shoots in different seasonal periods. The observation parameters consisted of five indicators, namely shoot number, shoot length, shoot elongation rate, shoot fresh weight, and shoot dry weight. Randomized complete block design using overseason was set up with three blocks. Each block was occupied by five different treatments, namely control, no addition $\mathrm{N}$, addition $2.33 \mathrm{~g} N$, addition $7.00 \mathrm{~g} \mathrm{~N}$, and $11.67 \mathrm{~g} \mathbf{N}$. Data analysis was conducted using ANOVA (5\%) and followed with HSD Tukey (5\%). Results demonstrated that there was a significant difference in the productivity of tea shoots in every treatment. The application of 3000 ppm organic + inorganic liquid fertilizer without Nitrogen addition performed the best outcome than others. This treatment significantly increased the productivity of fresh weight shoots around 56.34\% $\left(24.14\right.$-ton ha $^{-1}$ year $\left.^{-1}\right)$ higher than the control treatment $\left(10.54\right.$ ton ha $^{-1}$ year $\left.^{-1}\right)$. Interestingly, it also highly improved the production of dry weight shoots by around $61.51 \%\left(4.8\right.$ ton $^{-1}$ year $\left.^{-1}\right)$ greater than the control treatment $\left(1.84\right.$ ton $^{-1}$ year $\left.^{-1}\right)$. Thus, it was recommended to replace the conventional fertilization that was commonly implemented in the tea plantation with low productivity.
\end{abstract}

KEYWORDS

$\mathrm{N}$ addition, Organic + inorganic liquid fertilizers, Plantation, Productivity, Tea shoots

\section{INTRODUCTION}

The tea plant (Camellia sinensis (L.) O. Kuntze) is the most popular beverage plant in the world because of its high bioactive compounds and antioxidant properties contained in its shoots. Also, tea shoots are useful as raw materials for the functional food processing industry, herbal capsule formulations, tablets, herbs, cosmetics, shampoos, organic fertilizers, pesticides, herbicides, preservatives, and as raw materials for traditional health healing therapies [1][2][3]. The area of smallholder tea plantations dominates the area of tea plantations in Indonesia (46\%) with a low production rate of only $36 \%$ of the total national production because its 
management does not meet technical standards, the majority of Indonesian tea is old tea plants with low productivity [4].

Tea productivity is measured in terms of weight per unit area of land per year. The size of tea shoot weights is directly related to the fresh weight of shoots when picked. The number of shoots picked per unit area and the average weight per shoot is the yield component that determines the productivity of tea plants [5]. The number of shoots per unit area indicates higher productivity. Variation in shoot growth speed is the main parameter that causes variation in yield from season to season of certain genotypes [6][7][8]. The number of shoots and shoot weights are affected by the duration between two consecutive harvest times or the picking cycle. Weight per shoot is determined by picking standards, i.e. whether two leaves and one bud or three leaves and one bud are picked [9].

Besides climatic factors, technical knowledge of tea maintenance in commercial plantation, especially about the type, dosage, method, and application time of appropriate and balanced fertilizers play a vital role to increase the productivity of premium tea shoots. Therefore, it is necessary to stipulate a fertilizer application which be recommended to gain the results of premium tea shoots in a sustainable manner.

Nitrogen is one of the primary macronutrients that have an effect on increasing the productivity and quality of tea shoots optimally [10]. The application of nitrogen fertilizer is considered essential to maintain the yield of tea shoots economically [11]. The response of various tea clones to nitrogen fertilizer is very good at various locations [12]. Application of suitable nitrogen fertilizer dosage is one of nutrient management that can affect the growth, yield, and quality of tea shoots. Tea shrubs have a high level of sensitivity to the application of dose $\mathrm{N}$. The yield response to the application of the amount of $\mathrm{N}$ fertilizer is often in a quadratic pattern, with the highest yield in the range of doses of $200-400 \mathrm{~kg} \mathrm{~N}^{-1}$ [13]. Nitrogen doses up to the optimal level are usually applied to tea cultivation because the yield and quality of tea are significantly related to the total nitrogen content. Moreover, the productivity of tea is also potentially influenced by climate, particularly related to dry and wet conditions [14].

Climate change cannot be predicted precisely and has created uncertainty in the agricultural sector, including the productivity and quality of tea plants [15]. Changes in rainfall, sunlight intensity, temperature, humidity, and extreme weather conditions such as drought and high-intensity rainfall have negatively impacted the yield and quality of tea in the last few decades [16]. Therefore, intensive and sustainable application of technical innovation in tea cultivation related to local climate change is very much needed in tea plantations owned by the people, tea plantations owned by private companies, and state-owned tea plantations. The purpose of this study was to exam the addition of various levels of nitrogen concentrations to organic + inorganic liquid fertilizers to the productivity of tea shoots in the rainy and dry seasons.

\section{MATERIALS AND METHODS}

\section{Materials and Experimental Design}

The usage materials were fresh tea shoots of TRI 2025 clones as a result of the treatment of $\mathrm{N}$ addition in 3000 ppm of organic + inorganic liquid fertilizers which were done from January 2017 to January 2018 at the community tea plantation in Tritis, Ngargosari village, Samigaluh District, Kulon Progo, Yogyakarta. Altitude ranged $904 \mathrm{~m}$ above sea level. This study used an over season $5 \times 2$ complete randomized block design consisting of $\mathrm{N}$ addition factors in $3000 \mathrm{ppm}$ organic + inorganic liquid fertilizer and seasonal factors. Each factor repeated three times.

The treatment of $\mathrm{N}$ addition factors consisted of 5 levels, i.e. control, without $\mathrm{N}$ addition on organic + inorganic liquid fertilizer, but used the conventional fertilizer recommendation, namely $60 \mathrm{~g}$ urea, $10 \mathrm{~g} \mathrm{SP}-36$, and $20 \mathrm{~g}$ $\mathrm{KCl}$ plant $^{-1}$ ha $^{-1}(\mathrm{~N} 0), 0 \mathrm{~g} \mathrm{~N}(\mathrm{~N} 1), 2.33 \mathrm{~g} \mathrm{~N}(\mathrm{~N} 2), 7.00 \mathrm{~g} \mathrm{~N}(\mathrm{~N} 3)$, and $11.67 \mathrm{~g} \mathrm{~N}(\mathrm{~N} 4)$. Each N treatment was added at $3000 \mathrm{ppm}$ organic + inorganic liquid fertilizer. The volume of application for each treatment is 0.35 liters per plant through a fertigation irrigation system under shrubs at 10-day intervals after shoot picking. The season factors consisted of the rainy season and the dry season.

The source of $\mathrm{N}$ used as urea fertilizer. The formula of organic + inorganic liquid fertilizer contained a mixture of liquid organic fertilizer and the low nutrient hydroponic mineral solution made based on the formula of Resh (1981). The nutrient composition of liquid organic fertilizer consists of $0.72 \% \mathrm{~N} ; 0.1 \% \mathrm{P}_{2} \mathrm{O}_{5} ; 0.03 \% \mathrm{~K}_{2} \mathrm{O} ; 40$ ppm Ca; 10 ppm Mg; 12.6 ppm Fe; 5.8 ppm Cu; $5.21 \mathrm{ppm} \mathrm{Mn;} 4.29 \mathrm{ppm} \mathrm{Zn;} \mathrm{and} \mathrm{1.6 \%} \mathrm{amino} \mathrm{acids.} \mathrm{The}$

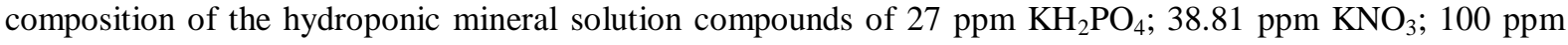
$\mathrm{Ca}\left(\mathrm{NO}_{3}\right)_{2} ; 49.97 \mathrm{ppm} \mathrm{MgSO}{ }_{4} .7 \mathrm{H}_{2} \mathrm{O} ; 66.66 \mathrm{ppm} \mathrm{S} ; 2$ ppm Fe EDTA; 0.5 ppm $\mathrm{MnSO}_{4} .7 \mathrm{H}_{2} \mathrm{O} ; 0.05 \mathrm{ppm} \mathrm{CuSO}_{4}$; $0.1 \mathrm{ppm} \mathrm{ZnSO} \mathrm{Z}_{4} ; 0,5 \mathrm{ppm}_{3} \mathrm{BO}_{3}$; and $0,02 \mathrm{ppm} \mathrm{NaMoO}$. Application of treatment of $\mathrm{N}$ addition in $3000 \mathrm{ppm}$ organic + inorganic liquid fertilizer was carried out at 10-day intervals after picking shoots for one year. To analyze the chlorophyll and EGCG levels, and the ability antioxidant activity of tea shoots from each treatment was picked in March and October 2017 to represent rainy and dry seasons. 
Zakarias F.M. Hukom et al., 2019. Effect of Nitrogen Addition to Organic + Inorganic Liquid Fertilizers and Seasons on Productivity of Tea Shoots. American-Eurasian Journal of Sustainable Agriculture. 13(4): 18-26. DOI: 10.22587/aejsa.2019.13.4.2

Table 1. Total $\mathrm{N}$ concentration of each treatment the $\mathrm{N}$ addition in $3000 \mathrm{ppm}$ organic + inorganic liquid fertilizers

\begin{tabular}{llccc}
$\begin{array}{l}\text { N addition in 3000 } \\
\text { organic }+ \text { inorganic } \\
\text { fertilizer }\end{array}$ & $\begin{array}{l}\text { Total N in organic }+ \\
\text { inorganic liquid fertilizer } \\
(\mathbf{p p m})^{*}\end{array}$ & $\begin{array}{l}\text { N-urea dosage in } \\
\text { block sample year } \\
-1\end{array}$ & $\begin{array}{l}\text { N-urea dosage } \\
\text { ha }^{-1} \text { year }^{-1}\end{array}$ \\
\hline Control & - & $1.325 .00 \mathrm{~g}$ & $383.3 \mathrm{~kg}$ \\
$0 \mathrm{~g} \mathrm{~N}$ & $105.00^{+}$ & $61.60 \mathrm{~g}$ & $17.80 \mathrm{~kg}$ \\
$2.33 \mathrm{~g} \mathrm{~N}$ & $260.00^{+}$ & $177.36 \mathrm{~g}$ & $51.32 \mathrm{~kg}$ \\
$7.00 \mathrm{~g} \mathrm{~N}$ & $571.33^{++}$ & $409.36 \mathrm{~g}$ & $118.44 \mathrm{~kg}$ \\
$11.67 \mathrm{~g} \mathrm{~N}$ & $882.67^{++}$ & $641.10 \mathrm{~g}$ & $185.57 \mathrm{~kg}$ \\
\hline
\end{tabular}

Note: sample area $=7.5 \mathrm{~m}^{2}$, spacing $=0.6 \times 1.2 \mathrm{~m}$, $*$ criteria for the range of nutrient concentrations for hydroponic plants,

${ }^{+}=$sufficient,${ }^{++}=$above average.

\section{Observation Parameters}

Observation of tea shoot productivity parameters included the number of shoots, shoot length, shoot fresh weight, shoot dry weight, and shoot yield. Observation of shoots productivity was carried out 37 times from each treatment with details of 21 times to represent the effect of treatment in the rainy season with rainfall conditions every 10 days interval $\geq 50 \mathrm{~mm}$ and 16 times to represent the effect of treatment in the dry season with rainfall conditions every 10 intervals day $<50 \mathrm{~mm}$. The productivity evaluation of tea shoots ha ${ }^{-1}$ uses the $^{-1}$ method of picking analysis on the fresh weight and shoot dry weight with the formula:

$$
\begin{aligned}
\text { Fresh weight }\left(\text { ton } h a^{-1}\right) & =\frac{\text { total population } \mathrm{ha}^{-1}}{\text { total sample population }} x \text { total sample fresh weight } \\
\text { Dry weight }\left(\text { ton } h a^{-1}\right) & =\frac{\text { total population } \mathrm{ha}^{-1}}{\text { total sample population }} x \text { total sample dry weight }
\end{aligned}
$$

\section{Data analysis}

Data were analyzed using ANOVA (5\%) and followed with HSD Tukey (5\%). The response pattern of the observed variables of each treatment was determined by regression-correlation analysis (5\%). Statistical analysis was conducted using an Excel program for Windows 2010.

\section{RESULTS AND DISCUSSION}

\section{Shoot number, shoot lengths and shoots extension rate}

In the table 2 evident that there is an interaction effect of $\mathrm{N}$ addition in $3000 \mathrm{ppm}$ organic + inorganic liquid fertilizer with season on shoot length and there is no interaction on shoots number and shoot extension rate, but there is an effect of $\mathrm{N}$ addition in $3000 \mathrm{ppm}$ organic + inorganic liquid fertilizer and season to number of shoots and rate of shoot extension.

The application of $3000 \mathrm{ppm}$ of organic + inorganic liquid fertilizer without the addition of $\mathrm{N}$ and or the addition of $2.33 \mathrm{~g} \mathrm{~N}$ and $7.00 \mathrm{~g} \mathrm{~N}$ has an effect on increasing the number of shoots of tea. This condition is caused by the total $\mathrm{N}$ concentration in organic + inorganic liquid fertilizer is in the range sufficient for plant needs (105.0 ppm) (Table 1) [11]. If the addition of $2.33-7.00 \mathrm{~g} \mathrm{~N}$ in $3000 \mathrm{ppm}$ organic + inorganic liquid fertilizer causes the total $\mathrm{N}$ concentration to increase to $260.00-531.33 \mathrm{ppm}$ so that it is in the range of the average concentration of plant requirements (Table 1) [7]. The concentration range is in a balanced condition in the soil solution so that it is easily absorbed by the roots for the synthesis of hormones and enzymes that are directly involved in the budding initiation process. The more buds formed have a direct effect on increasing the number of shoots in the picking field. The $\mathrm{N}$ addition relatively high $(11.67 \mathrm{~g} \mathrm{~N})$ caused a decrease in the number of shoots so that it was no different from plants that were not given organic + inorganic liquid fertilizer (control), because the addition of $11.67 \mathrm{~g} \mathrm{~N}$ increased $\mathrm{N}$ concentration in organic + inorganic liquid fertilizer so is above the average range of optimal levels for plant needs ( $882.67 \mathrm{ppm})$ (Table 1; Figure 1A). High nutrient $\mathrm{N}$ concentrations in soil solutions cause nutrient imbalance so that it affects the decrease in the ability of absorption of other nutrients by roots [17]. Thus, it can be stated that when the number of shoots of tea is low, the application of organic + inorganic liquid fertilizer is more effective and efficient in increasing the formation of shoots in the picking field. The number of shoots formed in the rainy season is higher than the dry season, 
Zakarias F.M. Hukom et al., 2019. Effect of Nitrogen Addition to Organic + Inorganic Liquid Fertilizers and Seasons on Productivity of Tea Shoots. American-Eurasian Journal of Sustainable Agriculture. 13(4): 18-26. DOI: 10.22587/aejsa.2019.13.4.2

because in the rainy season the sunlight, water, temperature, humidity, and nutrients in the soil are available sufficiently to support the synthesis of enzymes and growth hormones so that the process of division and enlargement of shoot meristematic cells tea can grow actively.

Table 2. The number of shoots, shoot lengths $(\mathrm{cm})$ and shoot elongation rate $(\mathrm{cm})$ at various levels of $\mathrm{N}$ addition on $3000 \mathrm{ppm}$ of organic + inorganic liquid fertilizer during the rainy and dry seasons.

\begin{tabular}{|c|c|c|c|c|c|c|c|c|c|}
\hline \multirow{2}{*}{$\begin{array}{l}\mathbf{N} \text { addition in } \\
3000 \text { ppm liquid } \\
\text { fertilizer organic } \\
+ \text { inorganic (g) }\end{array}$} & \multicolumn{3}{|c|}{ Shoot number } & \multicolumn{3}{|c|}{ Shoot length $(\mathrm{cm})$} & \multirow{2}{*}{$\begin{array}{l}\begin{array}{l}\text { Shoot } \\
\text { (cm) }\end{array} \\
\text { Rain } \\
\text { y }\end{array}$} & \multicolumn{2}{|c|}{ elongation rate } \\
\hline & Rainy & Dry & $\begin{array}{l}\text { Averag } \\
\text { e }\end{array}$ & $\begin{array}{l}\text { Rain } \\
\mathbf{y}\end{array}$ & Dry & $\begin{array}{l}\text { Averag } \\
\text { e }\end{array}$ & & Dry & $\begin{array}{l}\text { Averag } \\
\text { e }\end{array}$ \\
\hline & & & 6631.3 & & 3.5 & & & & \\
\hline Control & $\begin{array}{l}7078.7 \\
10758\end{array}$ & 6184.3 & $\begin{array}{l}\mathrm{d} \\
9992.2\end{array}$ & $3.8 \mathrm{f}$ & $\begin{array}{l}\mathrm{g} \\
5.1\end{array}$ & 3.6 & 0.58 & 0.54 & $0.56 \mathrm{~d}$ \\
\hline 0 & 7 & 9225.7 & $\begin{array}{l}\mathrm{a} \\
7695.7\end{array}$ & $5.9 \mathrm{a}$ & $\begin{array}{l}\mathrm{b} \\
4.2\end{array}$ & 5.5 & 0.82 & 0.73 & $0.78 \mathrm{a}$ \\
\hline 2.33 & 8323.7 & 7067.7 & $\begin{array}{l}\text { b } \\
7245.8\end{array}$ & $4.8 \mathrm{c}$ & $\begin{array}{l}\mathrm{d} \\
3.7\end{array}$ & 4.5 & 0.66 & 0.59 & $0.62 \mathrm{~b}$ \\
\hline 7 & 7646.3 & 6845.3 & $\begin{array}{l}\mathrm{c} \\
7141.5\end{array}$ & $4.3 \mathrm{~d}$ & $\begin{array}{l}\mathrm{f} \\
3.5\end{array}$ & 4.1 & 0.64 & 0.59 & $0.61 \mathrm{c}$ \\
\hline 11.67 & 7590.7 & 6692.3 & $\mathrm{~d}$ & $4.0 \mathrm{e}$ & $\mathrm{f}$ & 3.9 & 0.61 & 0.58 & $0.59 \mathrm{~d}$ \\
\hline & 8276.6 & 7203.1 & & & 4.0 & & 0.66 & 0.61 & \\
\hline Average & $\mathrm{p}$ & q & - & 4.55 & 7 & + & $\mathrm{p}$ & $\mathrm{q}$ & - \\
\hline $\operatorname{HSD} \alpha 5 \%$ & & 276.42 & 437.05 & & & 0.2 & & 0.02 & 0.03 \\
\hline
\end{tabular}

Note: Letters in rows or columns followed by the same letter show no significant effect on $\alpha 5 \%$, - = no interaction, ${ }^{+}=$interaction.

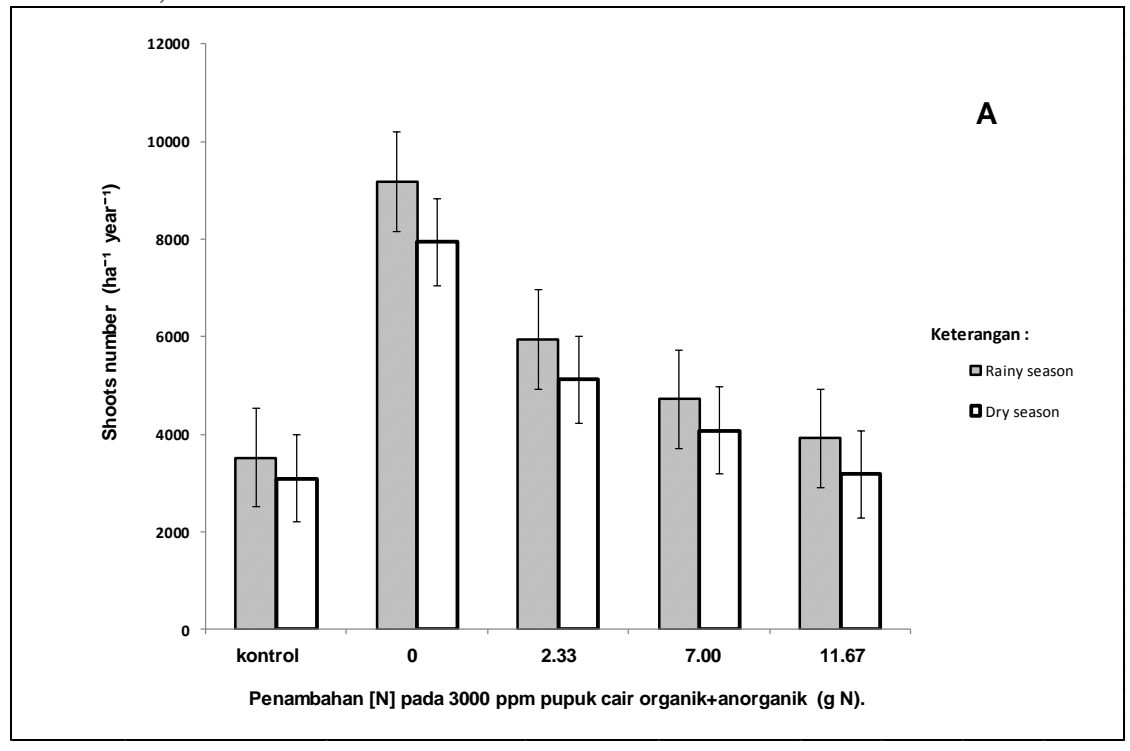



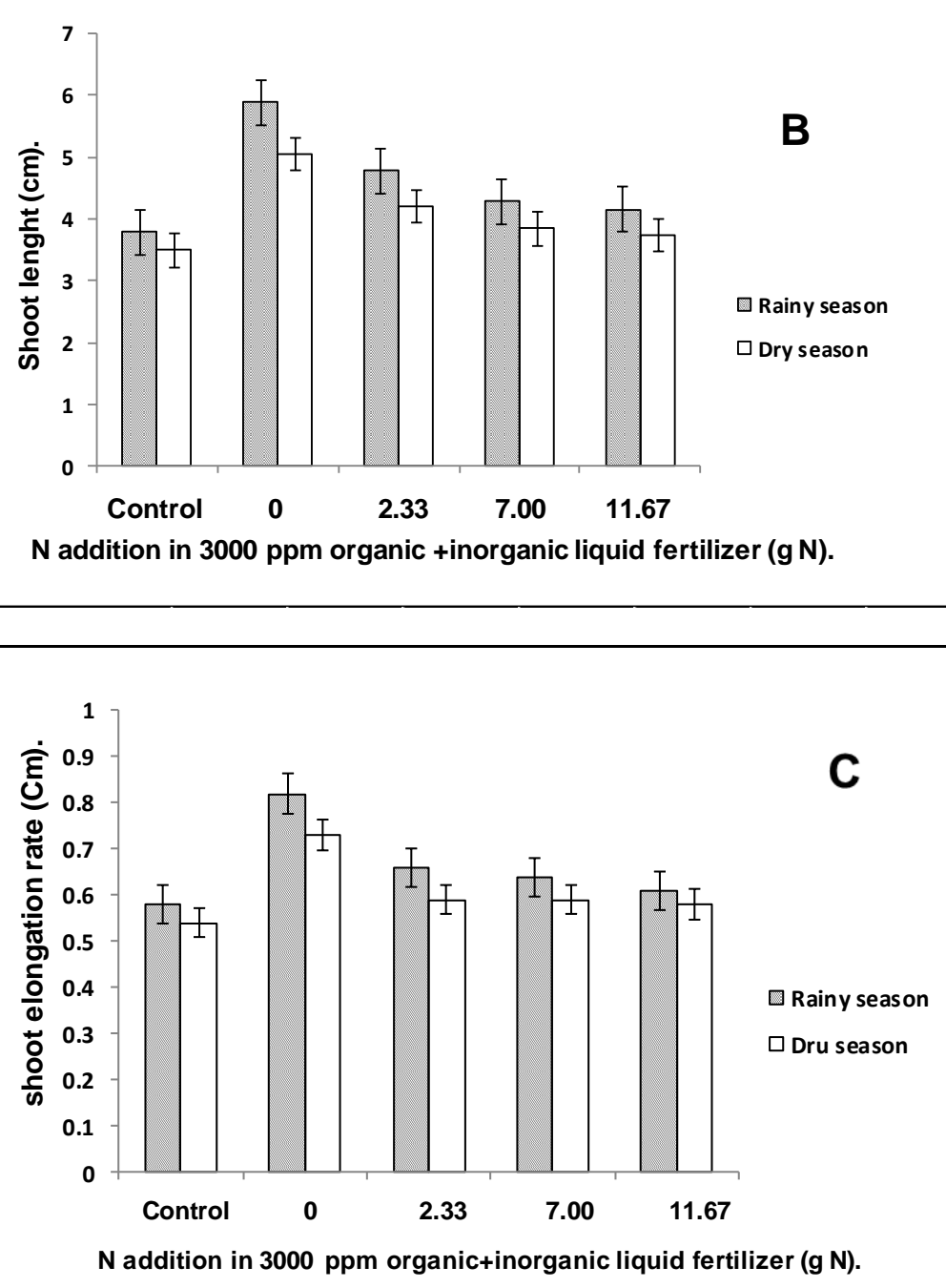

Figure 1. Graph: A) Number of shoots, B) Shoot length (cm), and C) shoot elongation rate (cm) at various increments of $(\mathrm{N})$ increase in organic + inorganic liquid fertilizer in the rainy and dry season.

The application of $3000 \mathrm{ppm}$ of organic + inorganic liquid fertilizer without $\mathrm{N}$ addition in the rainy season had the highest effect on increasing shoot length and $35.59 \%(2.1 \mathrm{~cm})$ of control plants in the rainy season and $40.68 \%(2.4 \mathrm{~cm})$ of control plants in the dry season and $13.56 \%(0.8 \mathrm{~cm})$ are longer than the shoots of tea which applicated $3000 \mathrm{ppm}$ of organic + inorganic liquid fertilizer in the dry season (Table 1;Figure 1B). This phenomenon is caused by the $\mathrm{N}$ concentration in the formula of organic+inorganic liquid fertilizer is in the range of sufficient concentration of $\mathrm{N}(105.00 \mathrm{ppm})$ for the synthesis of the amino acid L-tryptophan as a precursor of auxin hormone that functions in the process of division and enlargement of tea shoot cells actively [18]. The rainy season has a shoot size that is always longer than the dry season because in the rainy season, water, temperature, humidity, $\mathrm{N}$ nutrients and other macro and micronutrients are available in conditions sufficient to synthesize enzymes and growth hormones to stimulate bud formation and size shoot extension [19]. Table 2 and Figure 1C show that application $3000 \mathrm{ppm}$ of organic + inorganic liquid fertilizer without $\mathrm{N}$ addition or $2.33-7.00 \mathrm{~g} \mathrm{~N}$ addition has an effect on increasing the rate of elongation of tea shoots, because the total $\mathrm{N}$ concentrations in these three formulas range from $105.00-533.31 \mathrm{ppm}$ ( Table 1) so that it is in the range of level sufficient to average for plant growth. This condition indicates that the rate of shoot elongation is strongly influenced by the availability of $\mathrm{N}$ nutrients but the addition of relatively high $\mathrm{N}(11.67 \mathrm{~g} \mathrm{~N})$ in 3000 ppm of organic + inorganic liquid fertilizer until it is above the average plant requirement $(882.67 \mathrm{ppm}) \mathrm{has}$ an effect on reducing the elongation rate shoots. The rate of elongation of tea shoots in the rainy season is higher than the dry season as it influences the number of shoots. The faster rate of shoot elongation affects the size of the shoot length and weight per shoot [8]. 


\section{The fresh and dry weights of shoots}

In Table 3 and Figure 2A it is proven that the application of $3000 \mathrm{ppm}$ of organic + inorganic liquid fertilizer without the $\mathrm{N}$ addition gave a significant effect and 56.34\% higher than the fresh weight of the control plants and $39.02 \%$ and $51.04 \%$ higher than the addition of $2.33 \mathrm{~g} \mathrm{~N}$ and $11.67 \mathrm{~g} \mathrm{~N}$ in $3000 \mathrm{ppm}$ organic + inorganic liquid fertilizer. This phenomenon is caused by its effect on the formation of shoot number, shoot length and shoot elongation rate (Table 2). This fact is shown by the presence of a strong positive correlation between shoot fresh weight and shoot number, shoot length and shoot elongation rate (Table 4). The fresh weight of tea shoots in the rainy season is higher than the dry season because the intensity of sunlight in the rainy season is in the range of optimal sunlight intensity to increase the rate of photosynthesis to produce fresh shoots of tea compared to the dry season [20].

Table 3. Fresh shoot weights (ton ha ${ }^{-1}$ ), shoot dry weight (ton ha ${ }^{-1}$ ), and shoot yield (\%) at various levels of $\mathrm{N}$ addition on $3000 \mathrm{ppm}$ of organic + inorganic liquid fertilizer in the rainy and dry seasons.

\begin{tabular}{|c|c|c|c|c|c|c|c|c|c|}
\hline \multirow{2}{*}{$\begin{array}{l}\mathrm{N} \text { addition in } 3000 \\
\text { ppm liquid } \\
\text { fertilizer organic + } \\
\text { inorganic }(\mathrm{g})\end{array}$} & \multicolumn{3}{|c|}{ Shoot number } & \multicolumn{3}{|c|}{ Shoot length $(\mathrm{cm})$} & \multirow{2}{*}{$\begin{array}{l}\begin{array}{l}\text { Shoot } \\
(\mathrm{cm})\end{array} \\
\text { Rainy }\end{array}$} & \multicolumn{2}{|c|}{$\begin{array}{ll}\text { elongation rate } \\
\end{array}$} \\
\hline & Rainy & Dry & Average & Rainy & Dry & Average & & Dry & Average \\
\hline & & & & & 0.8 & & & 17.3 & \\
\hline Control & 5.62 & $\begin{array}{l}4.91 \\
11.1\end{array}$ & $5.27 \mathrm{~d}$ & 0.99 & 5 & $0.92 \mathrm{~d}$ & 17.65 & 3 & $17.49 \mathrm{c}$ \\
\hline 0 & 12.95 & 8 & $12.07 \mathrm{a}$ & 2.57 & $\begin{array}{l}2.2 \\
1.2\end{array}$ & $2.39 \mathrm{a}$ & 19.81 & $\begin{array}{l}19.7 \\
18.8\end{array}$ & $\begin{array}{l}19.75 \mathrm{a} \\
18.88\end{array}$ \\
\hline 2.33 & 7.94 & 6.78 & $7.36 \mathrm{~b}$ & 1.5 & $\begin{array}{l}8 \\
1.0\end{array}$ & $1.39 \mathrm{~b}$ & 18.9 & $\begin{array}{l}3 \\
18.5\end{array}$ & $a b$ \\
\hline 7 & 6.56 & 5.88 & $6.22 \mathrm{c}$ & 1.22 & $\begin{array}{l}9 \\
0.9\end{array}$ & $1.16 \mathrm{c}$ & 18.59 & $\begin{array}{l}3 \\
16.5\end{array}$ & $18.56 \mathrm{~b}$ \\
\hline 11.67 & 6.29 & 5.53 & $5.91 \mathrm{c}$ & 1.07 & 1 & $0.99 \mathrm{~d}$ & 17 & 4 & $16.77 \mathrm{c}$ \\
\hline & 7.9 & 6.9 & & 1.47 & 1.2 & & 18.39 & 18.1 & \\
\hline Average & $\mathrm{p}$ & $\mathrm{q}$ & - & $\mathrm{p}$ & $7 \mathrm{q}$ & - & $\mathrm{p}$ & $8 p$ & - \\
\hline $\operatorname{HSD} \alpha 5 \%$ & 0.27 & & 0.43 & 0.07 & & 0.12 & 0.23 & & 0.99 \\
\hline
\end{tabular}

Note: Letters in rows or columns followed by the same letter show no significant effect on $\alpha 5 \%$, - = no interaction.

Based on Table 1 and Table 3, the conversion of shoot fresh weight year ${ }^{-1}$ demonstrates that the application of liquid fertilizer without the $\mathrm{N}$ addition $\left(38.7 \mathrm{~kg}\right.$ urea ha ${ }^{-1}$ year $\left.{ }^{-1}\right)$ gives the highest increase in shoot fresh weight of 24.14 tons ha $^{-1}$ year ${ }^{-1}$ and more effective and efficient compared to the results obtained through conventional cultivation techniques (10.54 tons of fresh weight shoot ha ${ }^{-1}$ year ${ }^{-1}$ ) using a dose of urea fertilizer of $833.28 \mathrm{~kg} \mathrm{ha}^{-1}$ year $^{-1}$. This phenomenon is due to the fact that plants are more responsive to the availability of nutrient ions in certain concentrations which are much smaller than the provision of nutrients in the form of granules (solid form) [10]. This situation causes plant roots to be very sensitive to the concentration level of nutrient ions in soil solution, so that differences in nutrient ion concentrations in nutrient solution greatly affect the increase in shoot productivity.

Table 4. Correlation coefficients between observational variables

\begin{tabular}{lllllll}
\hline Variable & JP & Pp & LPp & BSP & BKP & Rend \\
\hline JP & 1 & & & & & \\
Pp & $0.81^{*}$ & 1 & & & & \\
LPp & $0.82^{*}$ & $0.99^{* *}$ & 1 & & & \\
BSP & $0.81^{*}$ & $0.97^{* *}$ & $0.98^{* *}$ & 1 & & \\
BKP & $0.96^{* *}$ & $0.98^{* *}$ & $0.98^{* *}$ & $0.88^{* *}$ & 1 & \\
Rend & $-0.65^{*}$ & $-0.66^{*}$ & -0.64 & $-0.58^{*}$ & - & $0.67 *$ \\
\hline
\end{tabular}

Note : $*$ significant $\alpha=0.05,{ }^{*}=$ significant $\alpha=0.01$. JP $=$ number of shoots, Pp $=$ shoot length, LPp $=$ rate of shoot extension, $\mathrm{BSP}=$ shoot fresh weight, $\mathrm{BKP}=$ shoot dry weight, and Rend $=$ shoot yield.

The application of 3000 ppm organic + inorganic liquid fertilizer without $\mathrm{N}$ addition gave significant effect and highest increase in shoot dry weight of $61.51 \%$ of the control plants and $41.84 \%$ and $51.46 \%$ of the plants which 
were given additional of 2.33 and $7.00 \mathrm{~g} \mathrm{~N}$. This phenomenon is the same as the effect on shoot fresh weight. The addition of relatively high $\mathrm{N}(11.67 \mathrm{~g} \mathrm{~N})$ had an effect on reducing shoot dry weight and did not differ from control plants, because the total $\mathrm{N}$ concentrations in the formula were in the range of concentrations above the average plant requirements or close to the maximum plant requirements (Table 1; Figure 2B). Dry shoot weight of tea shoots in the rainy season is higher $14.95 \%$ than dry season, because the number of shoots formed in the picking field and shoot shoots in the rainy season is higher than the dry season so that the net assimilation rate of the tea shoots in the rainy season is higher than dry season. High assimilation rate affects the productivity of shoot dry weight [3]. These results are consistent with the fact that there is a strong positive correlation between shoot dry weight and shoot number, shoot length, shoot elongation rate and shoot fresh weight (Table 4). The results of conversion of shoot dry weight on a ha ${ }^{-1}$ year scale based on Table 1 and Table 3 show that the application of liquid fertilizer without the addition of $\mathrm{N}$ concentration $\left(38.7 \mathrm{~kg}\right.$ urea ha ${ }^{-1}$ years $\left.{ }^{-1}\right)$ has $^{-1}$ influence on the highest shoot dry weight increase of 4.8 tons $^{\text {ha }^{-1}}$ years ${ }^{-1}$ and more effective and efficient compared to results obtained through conventional cultivation techniques (1.84 tons dry weight shoots ha ${ }^{-1}$ years) using a dose of urea fertilizer of $833.28 \mathrm{~kg} \mathrm{ha}^{-1}$ years ${ }^{-1}$ as the same as the effect on shoot fresh weight.
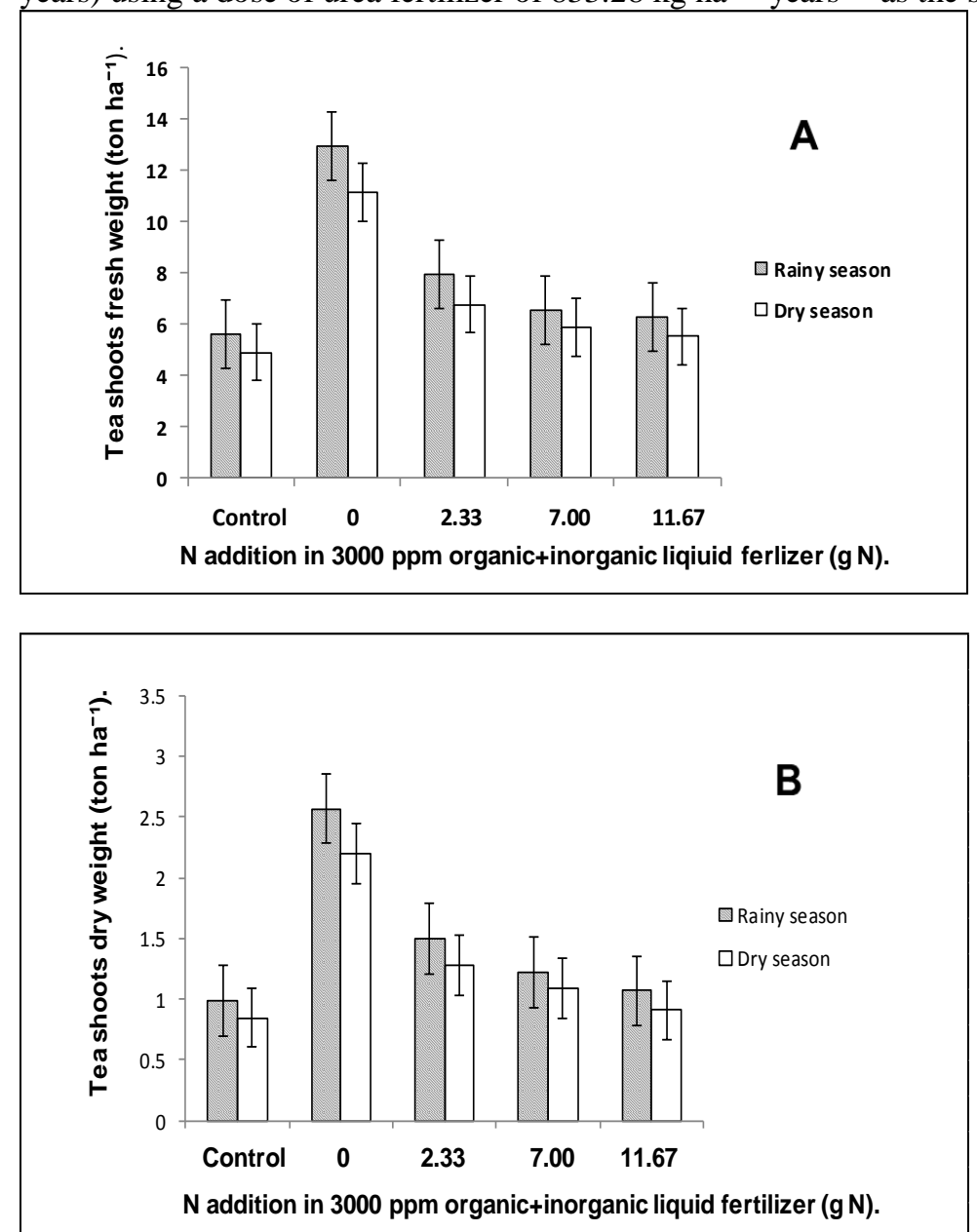

Figure 2. Graph: A) shoot fresh weight $(\mathrm{g})$, and B) shoot dry weight $(\mathrm{g})$ at various levels of addition of Nitrogen in liquid organic + inorganic fertilizer in the rainy and dry season, $\mathrm{O}+\mathrm{A}=$ organic + inorganic.

The application of 3000 ppm of organic + inorganic liquid fertilizer without $\mathrm{N}$ addition gave the highest effect on the formation of the best tea yields and was $11.44 \%$ higher than the control plants and respectively $6.03 \%$ and $15.09 \%$ higher than the plants given the addition of $7.00 \mathrm{~g} \mathrm{~N}$ and $11.67 \mathrm{~g} \mathrm{~N}$. This phenomenon is due to the formula having a high dry weight/shoot fresh weight ratio. The addition of relatively high of $\mathrm{N}(11.67 \mathrm{~g} \mathrm{~N})$ in $3000 \mathrm{ppm}$ of organic + inorganic liquid fertilizer affected the decrease in the percentage of tea shoot yield because it affected the decrease in dry weight. Thus it can be found that the application of 3000 ppm of organic + inorganic liquid fertilizer without $\mathrm{N}$ addition is more efficient to increase the productivity of tea shoots per unit area of land for one quotation period with better shoot rendering values. 
Zakarias F.M. Hukom et al., 2019. Effect of Nitrogen Addition to Organic + Inorganic Liquid Fertilizers and Seasons on Productivity of Tea Shoots. American-Eurasian Journal of Sustainable Agriculture. 13(4): 18-26. DOI: 10.22587/aejsa.2019.13.4.2

\section{CONCLUSION}

Giving 3000 ppm of organic + inorganic liquid fertilizer without the $\mathrm{N}$ addition in the rainy season has a significant effect on increasing the length of tea shoots. Giving $3000 \mathrm{ppm}$ of organic + inorganic liquid fertilizer without $\mathrm{N}$ addition gives a significant and higher effect on increasing number of shoots, shoot length, shoot elongation rate, shoot fresh weight, shoot dry weight and shoot yield. The rainy season has a significant effect on the number of shoots, shoot extension rates, fresh and dry weights of shoots but has no effect on shoot yield. The application of liquid fertilizer without the $\mathrm{N}$ addition has a significant effect on increasing the productivity of tea shoot fresh weight by 24.14 tons ha ${ }^{-1}$ years ${ }^{-1}$ or 4.8 tons dry weight ha ${ }^{-1}$ years ${ }^{-1}$ and higher is $56.34 \%$ and $61.51 \%$ on the productivity of fresh weights and dry weights of control plants.

\section{ACKNOWLEDGEMENTS}

The authors would like to thank Mr Purwanto as chairman of the Menoreh Jaya farmer group and staff who gave permission for the author to conduct research at the Tritis hamlet people's tea plantation, Ngargosari village, Samigaluh sub-district, Yogyakarta. This research was financially supported by domestic postgraduate education scholarship (BPP-DN), Director General of Science and Technology Resources and Higher Education (Dikti) RI.

\section{REFERENCES}

[1] Soni RP, Katoch M, Kumar A, Ladohiya R, Verma P. Tea: Production, Composition, Consumption and its Potential as an Antioxidant and Antimicrobial Agent. Int J Food Ferment Technol. 2015;5(2):95-105.

[2] Reygaert W. An Update on the Health Benefits of Green Tea. Beverages. 2017;3(4):6.

[3] Zhou Q, Chen Z, Lee J, Li X, Sun W. Proteomic analysis of tea plants (Camellia sinensis) with purple young shoots during leaf development. PLoS One [Internet]. 2017;12(5):1-18. Available from: http://dx.doi.org/10.1371/journal.pone.0177816

[4] Sita K, Hariadi SS, Subejo S. The Role of Tea Farmer Group in Tea Smallholder Downstream Supply Chain Cooperatives in West Java Province, Indonesia. KnE Life Sci. 2017;2(6):374.

[5] Jayasinghe HASL, Suriyagoda LDB, Karunarathne AS, Wijeratna MA. Modelling shoot growth and yield of Ceylon tea cultivar TRI-2025 (Camellia sinensis (L.) O. Kuntze). J Agric Sci. 2018;156(2):200-14.

[6] De Costa WAJM, Mohotti AJ, Wijeratne MA. Ecophysiology of tea. Brazilian J Plant Physiol. 2007;19(4):299332.

[7] Hajiboland R. Environmental and nutritional requirements for tea cultivation. Folia Hortic. 2017;29(2):199-220.

[8] Nyabundi KW, Owuor PO, Netondo GW, Bore JK. Seasonal and Environment Variations of Yields and Yield Components of Tea (Camellia sinensis) Cultivars in Kenya. Int J Tea Sci. 2017;13(01-02).

[9] Shah A, Hamid FS, Waheed A, Khan U. Impact of pruning and plucking on induction of axillary buds in tea. Int J Biosci. 2014;5(8):237-43.

[10] Gebrewold AZ. Review on integrated nutrient management of tea (Camellia sinensis L.). Cogent Food Agric [Internet]. 2018;4(1):1-12. Available from: https://doi.org/10.1080/23311932.2018.1543536

[11] Sitienei K, Home PG, Kamau DM, Wanyoko JK. Nitrogen and Potassium Dynamics in Tea Cultivation as Influenced by Fertilizer Type and Application Rates. Am J Plant Sci. 2013;04(01):59-65.

[12] Owuor PO, Ng'etich WK, Obanda M. Quality response of clonal black tea to nitrogen fertilizer, plucking interval and plucking standard. J Sci Food Agric. 2000;80(4):439-46.

[13] Kamau DM, Spiertz JHJ, Oenema O, Owuor PO. Productivity and nitrogen use of tea plantations in relation to age and genotype. F Crop Res. 2008;108(1):60-70.

[14] Ahmed S, Stepp JR, Orians C, Griffin T, Matyas C, Robbat A, et al. Effects of extreme climate events on tea (Camellia sinensis) functional quality validate indigenous farmer knowledge and sensory preferences in Tropical China. PLoS One. 2014;9(10).

[15] Ochieng J, Kirimi L, Mathenge M. Effects of climate variability and change on agricultural production: The case of small scale farmers in Kenya. NJAS - Wageningen J Life Sci. 2016;77(2016):71-8.

[16] Marx W, Haunschild R, Bornmann L. Global warming and tea production-the bibliometric view on a newly emerging research topic. Climate. 2017;5(3):1-14.

[17] Santosh KC, Liu M, Zhang Q, Fan K, Shi Y, Ruan J. Metabolic changes of amino acids and flavonoids in tea plants in response to inorganic phosphate limitation. Int J Mol Sci. 2018;19(11):1-21.

[18]Zhao XQ, Shen RF. Aluminum-nitrogen interactions in the soil-plant system. Front Plant Sci. 2018;9(June):115. 
Zakarias F.M. Hukom et al., 2019. Effect of Nitrogen Addition to Organic + Inorganic Liquid Fertilizers and Seasons on Productivity of Tea Shoots. American-Eurasian Journal of Sustainable Agriculture. 13(4): 18-26. DOI: 10.22587/aejsa.2019.13.4.2

[19] Duncan JMA, Saikia SD, Gupta N, Biggs EM. Observing climate impacts on tea yield in Assam, India. Appl Geogr. 2016;77:64-71.

[20] Fan XX, Xu ZG, Liu XY, Tang CM, Wang LW, Han X lin. Effects of light intensity on the growth and leaf development of young tomato plants grown under a combination of red and blue light. Sci Hortic (Amsterdam) [Internet]. 2013;153:50-5. Available from: http://dx.doi.org/10.1016/j.scienta.2013.01.017 